Supporting Information for

\title{
DNA Aptamer Folding on Gold Nanoparticles: from Colloid Chemistry to Biosensors
}

\author{
Weian Zhao, ${ }^{1}$ William Chiuman, ${ }^{2}$ Jeffrey C. F. Lam, ${ }^{2}$ Simon A. McManus, ${ }^{2}$ Wei Chen, ${ }^{3}$ Yuguo Cui, ${ }^{3}$ \\ Robert Pelton, ${ }^{3}$ Michael A. Brook ${ }^{1}$ and Yingfu $\mathrm{Li}^{2,1} *$
}

1. Department of Chemistry, 2. Department of Biochemistry and Biomedical Sciences and 3. Department of Chemical Engineering, McMaster University, 1200 Main St., W. Hamilton, ON, L8N $3 Z 5$ (Canada)

*To whom correspondence should be addressed. E-mail: liying@mcmaster.ca or mabrook@mcmaster.ca.

\section{Experimental Section}

1.1 Materials. Trisodium citrate, hydrogen tetrachloroaurate(III) ( $\left.\mathrm{HAuCl}_{4}\right)$, 6-mercaptohexan-1-ol $(\mathrm{MCH})$, adenosine, adenosine 5'-triphosphate (ATP), potassium chloride $(\mathrm{KCl})$, sodium chloride $(\mathrm{NaCl})$, lithium chloride ( $\mathrm{LiCl})$, inosine, erythro-9-(2-hydroxy-3-nonyl)adenine (EHNA), ethyl acetate and adenosine deaminase (ADA) were purchased from Sigma and used as received. [ $\left.-{ }^{32} \mathrm{P}\right]$-ATP was obtained from Amersham Biosciences. DNA molecules were obtained from Integrated DNA Technologies (IDT).

1.2 Preparation of aptamer-modified AuNPs. AuNPs $(\sim 13.5 \mathrm{~nm}$ in diameter based on transmission electron microscopy (TEM) measurement) were prepared according to previously described protocols. ${ }^{1}$ The concentration was estimated using UV/vis spectroscopy to be $\sim 13 \mathrm{nM}$, based on an extinction coefficient of $2.7 \times 10^{8} \mathrm{M}^{-1} \mathrm{~cm}^{-1}$ at $\lambda=520 \mathrm{~nm}$. ${ }^{1 \mathrm{a}}$ Aptamer-modified AuNPs were then prepared using the standard surface modification protocol based on Au-S chemistry. ${ }^{1}$ Briefly, an AuNP solution $(600 \mu \mathrm{L}$, $\sim 13 \mathrm{nM}$ ) was mixed with thiol-modified oligonucleotides $(280 \mu \mathrm{L}, 6.6 \mu \mathrm{M})$ (see Table 1 for the sequences of adenosine, $\mathrm{K}^{+}$aptamers and their mutants). The solution was incubated at room temperature for $12 \mathrm{~h}$. Tris- $\mathrm{HCl}$ buffer $(10 \mu \mathrm{L}, 1 \mathrm{M}, \mathrm{pH} 7.5)$ and aqueous $\mathrm{NaCl}(90 \mu \mathrm{L}, 1 \mathrm{M})$ were added, and the mixture was incubated for another $12 \mathrm{~h}$. After that, Tris- $\mathrm{HCl}$ buffer $(5 \mu \mathrm{L}, 1 \mathrm{M}, \mathrm{pH} 7.5)$ and aqueous $\mathrm{NaCl}(50 \mu \mathrm{L}, 5 \mathrm{M})$ were added, and the mixture was further incubated for $18 \mathrm{~h}$ at room temperature. The solution was then separated by a centrifuge at $22000 \mathrm{~g}$ for $15 \mathrm{~min}$. The precipitated aptamer-modified AuNPs were washed with double-deionized (dd) $\mathrm{H}_{2} \mathrm{O}(600 \mu \mathrm{L})$ and isolated using centrifugation. Finally, adenosine aptamer-modified AuNPs (referred to as Au-Ado and Au-T10Ado for the aptamer without and with T10 linker, respectively) and $\mathrm{K}^{+}$aptamer-modified AuNPs (referred to as $\mathrm{Au}-\mathrm{K}$ ) were redispersed in $600 \mu \mathrm{L}$ adenosine buffer (Tris- $\mathrm{HCl}(20 \mathrm{mM}), \mathrm{pH}=7.5, \mathrm{NaCl}(100$ $\mathrm{mM})$ ) and $\mathrm{ddH}_{2} \mathrm{O}$, respectively. For the synthesis of radioactive oligonucleotide, $\left[\gamma^{32} \mathrm{P}\right] \mathrm{ATP}(20 \mu \mathrm{Ci})$ was incorporated using the manufacturer-supplied protocol.

1.3 MCH treatment. The aptamer-modified AuNPs were treated with MCH as described elsewhere. ${ }^{2}$ Briefly, Au-Ado (or Au-T10Ado) solution prepared above was diluted with an equal volume of adenosine buffer, $\mathrm{MCH}$ was then added to give a final $\mathrm{MCH}$ concentration of $\sim 4 \mu \mathrm{M}$. The $\mathrm{MCH}$ treatment was performed at room temperature for $30 \mathrm{~min}$. The reaction was quenched by three washes with equal volumes of ethyl acetate, which removed excess $\mathrm{MCH}$ from the aqueous solution. A similar procedure was used for $\mathrm{Au}-\mathrm{K}$ with an exception that $\mathrm{ddH}_{2} \mathrm{O}$ was used instead of adenosine buffer. The aptamer-modified AuNPs were spun down using centrifugation at $22000 \mathrm{~g}$ for $15 \mathrm{~min}$. The final AuAdo (or Au-T10Ado) and Au-K were redispersed in $600 \mu \mathrm{L}$ adenosine buffer and $\mathrm{ddH}_{2} \mathrm{O}$, respectively. 
1.4 Au-Ado (or Au-T10Ado) stability with and without adenosine. Adenosine aptamer folding on AuAdo (or Au-T10Ado) was conducted in a solution that contained Au-Ado (or Au-T10Ado) ( $3 \mathrm{nM}$ ), adenosine $(1 \mathrm{mM})$, Tris- $\mathrm{HCl}(20 \mathrm{mM}), \mathrm{pH}=7.5,4 \mathrm{mM} \mathrm{MgCl}_{2}$ and $\mathrm{NaCl}(100 \mathrm{mM})$. At this salt concentration (4 mM MgCl 2 and100 mM NaCl), both Au-Ado (or Au-T10Ado) and Au-Ado with folded aptamer/adenosine complex (referred to as Au-Ado-Target) (or Au-T10Ado-Target) were stable and the solutions appeared red. To determine their stability, $\mathrm{MgCl}_{2}(1 \mathrm{M})$ solution was gradually added into AuNP solutions until a red-to-purple color change was observed over a short period of time $(\sim 1$ $\min )$.

1.5 Au-K stability with and without $\mathrm{K}^{+} . \mathrm{K}^{+}$aptamer folding on $\mathrm{Au}-\mathrm{K}$ was performed in an aqueous solution containing $\mathrm{Au}-\mathrm{K}(\sim 3 \mathrm{nM})$ and $\mathrm{KCl}(10 \mathrm{mM})$. Using a strategy that is similar to the adenosine system, the stability of $\mathrm{Au}-\mathrm{K}$ and $\mathrm{Au}-\mathrm{K}$ with the folded aptamer $/ \mathrm{K}^{+}$complex (referred to as Au-KTarget) was studied by gradually adding $\mathrm{MgCl}_{2}(1 \mathrm{M})$ until a red-to-purple color change was observed over a short period of time $(\sim 1 \mathrm{~min})$.

1.6. Adenosine and $\mathrm{K}^{+}$sensing assays. In the case of adenosine, assay solutions $(250 \mu \mathrm{L})$ contained various amounts of adenosine, Au-T10Ado ( $3 \mathrm{nM})$, Tris- $\mathrm{HCl}(20 \mathrm{mM}), \mathrm{pH}=7.5, \mathrm{NaCl}(100 \mathrm{mM})$ and $\mathrm{MgCl}_{2}(60 \mathrm{mM})$. Specifically, a mixture $(180 \mu \mathrm{L})$ of Au-T10Ado $(\sim 4.14 \mathrm{nM})$, Tris-HCl $(28 \mathrm{mM})$ and $\mathrm{NaCl}(138 \mathrm{mM})$ was first prepared. A solution $(70 \mu \mathrm{L})$ of $\mathrm{MgCl}_{2}(214 \mathrm{mM})$ and various amounts of adenosine were then added, after which UV-visible spectra were recorded continuously on a Cary 300 $\mathrm{UV} /$ vis spectrophotometer for $10 \mathrm{~min}$ at room temperature $\left(21^{\circ} \mathrm{C}\right)$ or $35^{\circ} \mathrm{C}$.

A similar assay was performed for the detection of $\mathrm{K}^{+}$. Briefly, assay solutions $(250 \mathrm{~L})$ contained various amounts of $\mathrm{K}^{+}$, Au-K $(\sim 3 \mathrm{nM})$, and $\mathrm{MgCl}_{2}(20 \mathrm{mM})$. UV-visible spectra were recorded continuously on a Cary300 UV/vis spectrophotometer for $10 \mathrm{~min}$ at room temperature immediately after the addition of $\mathrm{KCl}$ and $\mathrm{MgCl}_{2}$.

1.7. Adenosine deaminase (ADA) sensing assay. Au-T10Ado $(\sim 3 \mathrm{nM})$ was mixed with adenosine $(1$ $\mathrm{mM})$ solution in a buffer containing Tris- $\mathrm{HCl}(20 \mathrm{mM}), \mathrm{pH}=7.5, \mathrm{MgCl}_{2}(60 \mathrm{mM})$ and $\mathrm{NaCl}(100 \mathrm{mM})$. Various amounts of ADA were then added, after which UV-visible spectra were recorded on Cary300 UV/vis spectrophotometer at room temperature. To study the inhibition, the ADA inhibitor, EHNA $(400 \mu \mathrm{M})$, was incorporated in above Au-T10Ado solution before the addition of ADA.

1.8. Characterizations. TEM samples were prepared by dropping AuNP solutions (4 $\mu \mathrm{L})$ onto a carbon-coated copper grid. The solution was wicked from the edge of the grid with a piece of filter paper after $1 \mathrm{~min}$. TEM images were taken with a JEOL $1200 \mathrm{EX}$. UV-visible spectra were recorded on a Cary300 UV/vis spectrophotometer. Dynamic light scattering (DLS) measurements were performed at $25^{\circ} \mathrm{C}$ and a scattering angle of $90^{\circ}$ using a Brookhaven (Holtsville, NY) 256 channel BI-APD 8590 correlator and a $35 \mathrm{~mW} 632.8 \mathrm{~nm}$ laser. The particle size (diameter) was calculated by cumulative intensity distribution using the program CONTIN. Each reported particle size was the average of 10 measurements. 


\section{Supporting Figures}

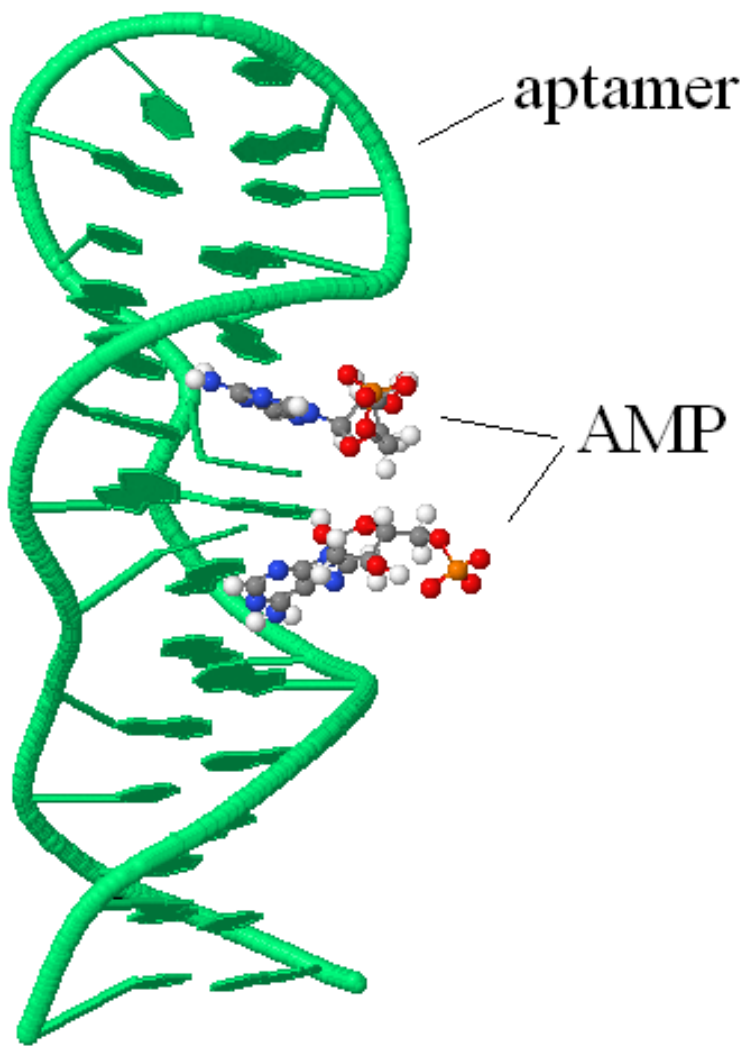

Figure S1. Three-dimensional model for folded DNA aptamer/adenosine monophosphate (AMP) complex. This structure, obtained based on a previous NMR study, ${ }^{3}$ is adopted from the RCSB protein data bank. Aptamer backbone together with nucleobases are shown in green. In AMP model structure, $\mathrm{C}, \mathrm{N}, \mathrm{O}, \mathrm{P}$ and $\mathrm{H}$ are shown in grey, blue, red, orange and white, respectively. One aptamer/AMP complex contains two adjacently bound AMP molecules. Detailed structural information can be found in reference 3.

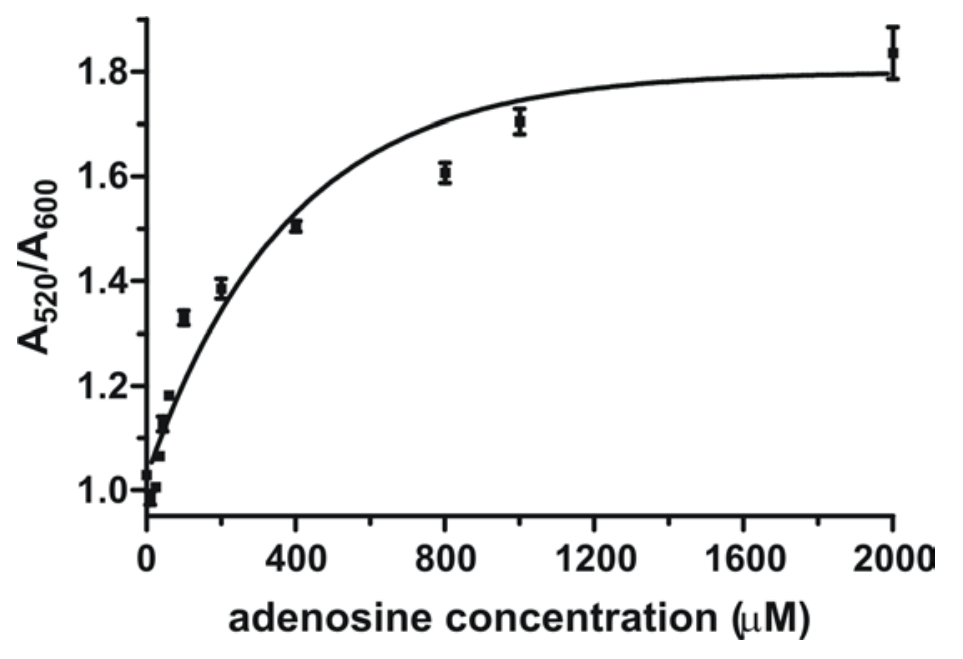


Figure S2. Determination of the dissociation constant $\left(\mathrm{K}_{\mathrm{d}}\right)$ for adenosine-binding DNA aptamer. The $\mathrm{A}_{520} / \mathrm{A}_{600}$ (abbreviated as $\mathrm{A}$ ) vs. adenosine concentration data were fit into a modified one phase exponential association equation, $\mathrm{A}=\mathrm{A}_{\min }+\left(\mathrm{A}_{\max }-\mathrm{A}_{\min }\right) \times\left(1-\mathrm{e}^{-\mathrm{k}[\text { adenosine }]}\right)$, where the best-fit $\mathrm{A}_{\min }=$ 1.026 with the $A_{\max }$ constraint of $\geq 1.8$, with $R^{2}=0.95$. $K_{d}$ was approximated from the mid-point of the equation, $-\ln (0.5 / \mathrm{k})$, where $\mathrm{k}$ (an arbitrary constant) has a value of 0.002632 . By this method, a $\mathrm{K}_{\mathrm{d}}$ of $263 \mu \mathrm{M}$ was obtained.

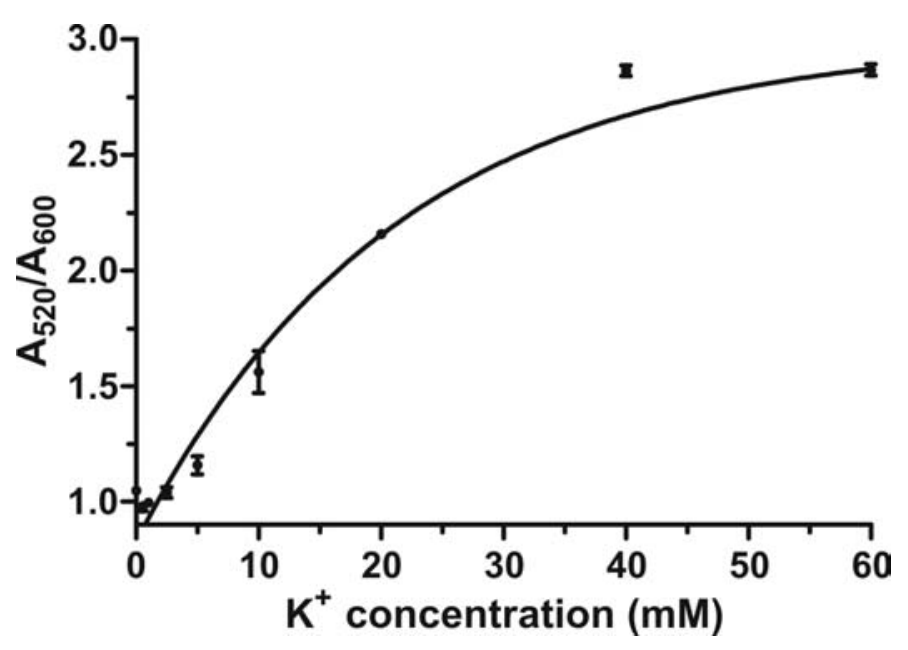

Figure 3. Determination of $K_{d}$ for potassium ion-binding DNA aptamer. The $A_{520} / A_{600}$ vs. potassium concentration data were fit into a modified one phase exponential association equation, $\mathrm{A}=\mathrm{A}_{\min }+$ $\left(A_{\max }-A_{\min }\right) \times\left(1-e^{-k[\text { potassium }]}\right)$, where the best-fit $A_{\min }=0.83$ with the $A_{\max }$ constraint $=3$, with $R^{2}=$ $0.98 . K_{d}$ was approximated from the mid-point of the equation, $-\ln (0.5 / \mathrm{k})$, where $\mathrm{k}$ has a value of 0.047 . By this method, a $\mathrm{K}_{\mathrm{d}}$ of $15 \mathrm{mM}$ was obtained.

\section{References}

(1) (a) Hill, H. D.; Mirkin, C. A. Nat. Protocols. 2006, 1, 324-336. (b) Liu, J.; Lu, Y. Nat. Protocols 2006, 1, 246-252.

(2) (a) Park, S.; Brown, K. A.; Hamad-Schifferli, K. Nano Lett. 2004, 4, 1925-1929. (b) Huang, E.; Satjapipat, M.; Han, S.; Zhou, F. Langmuir 2001, 17, 1215-1224. (c) Zhao, W.; Chiuman, W.; Brook, M. A.; Li, Y. ChemBioChem. 2007, 8, 727-731.

(3) Lin, C. H.; Patel, D. J. Chem. Biol. 1997, 4, 817-832. 